Research article

\title{
DIAGNOSTICS AND GENOTYPING OF CANINE PARVOVIRUS TYPE 2 (CPV-2) FROM DISEASE CASES IN SOUTH-EASTERN POLAND
}

\author{
KOWALCZYK Marek ${ }^{1}$, MAJER-DZIEDZIC Barbara², KOSTRO Krzysztof ${ }^{3}$, \\ SZABELAK Aleksandra ${ }^{1}$, ZIETTEK Jerzy ${ }^{3}$, GRYZINSKA Magdalena ${ }^{1 *}$, \\ JAKUBCZAK Andrzej ${ }^{1}$
}

${ }^{1}$ Institute of Biological Basis of Animal Production, Faculty of Biology, Animal Science and Bioeconomy, University of Life Sciences Lublin, Poland; ${ }^{2}$ Sub-Department of Veterinary Microbiology, Faculty of Veterinary Medicine, University of Life Sciences Lublin, Poland; ${ }^{3}$ Department of Epizootiology and Clinic of Infectious Diseases, Faculty of Veterinary Medicine, University of Life Sciences Lublin, Poland

(Received 23 July 2018, Accepted 18 February 2019)

Canine parvovirus type 2 is one of the most common causes of death among puppies. Despite preventive vaccination, the disease continues to be diagnosed. The aim of the study was to provide a molecular characterization of CPV-2 isolates found in southeastern Poland. Genetic CPV-2 material was isolated from the blood $(n=10)$ and feces $(n=50)$ of infected dogs. The presence of CPV-2 was confirmed by amplification of sequences coding both VP1 and VP2 protein. The products of the PCR reaction with primers amplifying VP2 protein were sequenced and used for genotyping. Bioinformatics analysis of the sequenced PCR product was performed to determine the phylogenetic relationships with variants recorded in the public databases. Based on the analysis of polymorphism in the nucleotide sequence 7 nucleotide variants were detected and assigned into four amino acid groups. Representatives of three groups contained asparagine at amino acid position 426 of the VP2 protein, which is characteristic of CPV-2a. The variant from the fourth group belonged to type CPV-2b. $\mathrm{CPV}-2 \mathrm{a}$ is the dominant antigenic type of CPV-2 in Poland. The pathogen's high degree of polymorphism is manifested not only by the presence of numerous variants within the type, but also by the presence of representatives of type CPV-2b. Further studies of the molecular epidemiology of CPV-2 are necessary to optimize the effectiveness of preventive measures.

Key words: canine parvovirus type 2, molecular diagnostics, phylogenetics, VP2 protein

\section{INTRODUCTION}

Despite the widespread use of specific immunoprophylaxis, parvovirus infections in dogs are a current problem worldwide. The acute course of the disease and high

*Corresponding author: e-mail: magdalena.gryzinska@up.lublin.pl 
mortality among puppies under the age of six months make the parvovirus infection one of the most dangerous diseases in young dogs. The etiologic agent of the disease is a non-enveloped virus of the genus Parvovirus, subfamily Parvovirinae, family Parvoviridae [1].

The genetic material of CPV-2 is a single-stranded DNA with a length of $5.3 \mathrm{~kb}$. Two open reading frames enable translation of fragments encoding two non-structural proteins (NS1 and NS2) and two structural proteins (VP1 and VP2). During CPV-2 infection, digestion of the VP2 protein by a host protease results in the formation of the VP3 protein [2].

CPV-2 infection was first diagnosed in the 1970s. The virus has since undergone intensive evolution, resulting after three decades in the emergence of three types, CPV2a, CPC-2b and CPV-2c, [3-5], which supplanted the original variant. Its substantial genetic variation, with a similar substitution rate to that of viral RNA [6], entails difficulty in selecting both diagnostic tests and vaccine antigens. What is more, due to the presence of maternal antibodies, vaccination may be not as effective as it is needed. Therefore, diagnostics plays a crucial role in CPV-2 prophylaxis [7].

Classical diagnostic methods are not always sufficiently sensitive, which makes precise identification of a disease entity difficult [3]. For this reason, molecular methods with a higher sensitivity and specificity are increasingly used for routine diagnostics $[8,9]$. The leading method of canine parvovirus diagnosis is PCR (Polymerase Chain Reaction) and its modifications, such as Real-Time PCR [10,11], multiplex PCR [12], and nested PCR [13]. Owing to the high sensitivity and specificity of the PCR technique, the CPV2 genetic material can be detected directly at an early stage of infection. An additional advantage of molecular techniques based on amplification of nucleic acids is that the variants obtained can be genotyped by sequencing or using appropriate probes in a qPCR reaction $[3,8]$. Knowledge of the dominant CPV-2 variants in a given area makes it possible to select a vaccine antigen that provides effective protection against infection [14].

Poland is a country with a relatively poorly characterized molecular epidemiology. Given the high rate of evolution of the virus, existing research results must be updated and supplemented. The aim of the study was to examine the molecular variability of Polish CPV-2 isolates, determine their antigenic variants, and present their relationship with variants from other countries.

\section{MATERIAL AND METHODS}

Samples were collected from 116 dogs with gastrointestinal signs during 2008-2016. To identify CPV-2 in the feces of dogs with suspected parvovirus infection, we used the commercial immunochromatographic test Speed Parvo ${ }^{\circledR}$ (Virbac), based on specific monoclonal antibodies. Sixty samples were selected for further tests. The research material consisted of feces $(n=50)$ and blood $(n=10)$ from dogs with acute diarrhea, 
vomiting, and fever, in which infection was confirmed by an immunochromatographic test.

To avoid false negative results caused by the presence of enzyme reaction inhibitors in the feces, the virus was isolated from the feces and cultured. Blood samples from dogs with confirmed infection were used directly as the material for further testing. The study was performed according to statutory bioethical standards and approved by the Local Ethics Commission of the University of Life Sciences in Lublin, approval number 83/2009.

\section{Isolation of the virus from feces}

The virus was isolated from the feces of dogs with confirmed infection $(n=50)$. Samples of intestinal contents was diluted in PBS in the ratio 1:10 and mixed with chloroform (one part of chloroform with ten parts of sample). The mixture was vortexed and incubated for 12 hours at $4^{\circ} \mathrm{C}$ and centrifuged at $2000 \mathrm{~g}$ for $15 \mathrm{~min}$. The supernatant was treated with penicillin, streptomycin, amphotericin and tylosin, incubated and mixed for $30 \mathrm{~min}$ at $20^{\circ} \mathrm{C}$. After incubation, the supernatant was filtered through a $0.45 \mu \mathrm{m}$ and $0.2 \mu \mathrm{m}$ filter (Millipore ${ }^{\mathrm{TM}}$ ). After confirming the hemagglutination activity of the resulting filtrate, it was used to inoculate a culture of the continuous cell line CCC clone 81 (clone 81 of transformer feline kidney cells). A cytopathic effect was obtained after the first blind passage. After five passages, the hemagglutination titre was measured and found to be in the range of 400-3,200, while the cell culture infectious dose $\left(\mathrm{CCID}_{50} \mathrm{ml}^{-1}\right)$ ranged from $10^{3.5}$ to $10^{5.5}$. The strains were freeze-dried and pooled for further studies.

\section{DNA extraction and amplification}

DNA was extracted from cell cultures showing cytopathic effects $(n=50)$ and from blood samples obtained from dogs with positive results of Speed Parvo test $(n=10)$. Viral DNA was isolated from the cell culture and blood with a QIAmp DNA Mini Kit (Qiagen) and the genetic material was subjected to electrophoretic evaluation. A PCR reaction was conducted to detect the genetic material of the CPV-2 virus in the blood of the animals. Two primers pairs were used for the reaction. The first pair (V1) amplified the coding sequence of a VP2 protein fragment, and the second pair (V2) amplified the entire CPV-2 capsid protein. The primer sequences, reaction conditions and mixture composition are given in Tables 1 and 2. The optimum amplification temperature was established by modifying the reaction conditions using a thermal gradient and a magnesium concentration gradient. PCR products were separated in a $1 \%$ agarose gel with ethidium bromide at $60 \mathrm{~V}$. 
Table 1. Primer sequences used for PCR, product lengths obtained after amplification, and references to studies in which the primers were first used

\begin{tabular}{cclcc}
\hline \multicolumn{2}{c}{ Primername } & \multicolumn{1}{c}{ Sequence of Primer } & $\begin{array}{c}\text { Length of } \\
\text { Product }\end{array}$ & References \\
\hline \multirow{2}{*}{ V1 } & F & 5'-ATTTCTACGGGTGCTTTC-3' & $374 \mathrm{bp}$ & {$[2]$} \\
& R & 5'-ACT'TTAGTTGGTGGCTGA-3' & & \\
\multirow{2}{*}{ V2 } & F & 5'-CT'TACGCTGCTTATCTTCGCTCTGG-3' & $2487 \mathrm{bp}$ & {$[5]$} \\
& R & 5'-T'TTTGGTCCTTAACATATTCTAAGGGCAA-3' & \\
\hline
\end{tabular}

Table 2. Reaction mix composition and temperature profiles for each primer pair

\begin{tabular}{|c|c|c|c|c|}
\hline Reaction mix & \multicolumn{2}{|c|}{ Primer V1 } & \multicolumn{2}{|c|}{ Primer V2 } \\
\hline Water & \multicolumn{2}{|c|}{ to $25 \mu \mathrm{l}$} & \multicolumn{2}{|c|}{ to $25 \mu \mathrm{l}$} \\
\hline Buffer 10x & \multicolumn{2}{|c|}{$1 \mathrm{x}$ concentrated } & \multicolumn{2}{|c|}{ 1x concentrated } \\
\hline GC Enhancer & \multicolumn{2}{|c|}{$0.05 x$ concentrated } & \multicolumn{2}{|c|}{$0.05 x$ concentrated } \\
\hline $\mathrm{Mg} 2+$ & \multicolumn{2}{|c|}{$3 \mathrm{mM}$} & \multicolumn{2}{|c|}{$2.5 \mathrm{mM}$} \\
\hline dNTP & \multicolumn{2}{|c|}{$0.8 \mathrm{mM}$} & \multicolumn{2}{|c|}{$0.8 \mathrm{mM}$} \\
\hline Starter Forward & \multicolumn{2}{|c|}{$0.8 \mu \mathrm{M}$} & \multicolumn{2}{|c|}{$0.8 \mu \mathrm{M}$} \\
\hline Starter Reverse & \multicolumn{2}{|c|}{$0.8 \mu \mathrm{M}$} & \multicolumn{2}{|c|}{$0.8 \mu \mathrm{M}$} \\
\hline Polymerase & \multicolumn{2}{|c|}{$1.3 \mathrm{U}$} & \multicolumn{2}{|c|}{$1.3 \mathrm{U}$} \\
\hline Thermal Profile & Temperature & Time & Temperature & Time \\
\hline Initial Denaturation & $95^{\circ} \mathrm{C}$ & $10 \mathrm{~min}$ & $95^{\circ} \mathrm{C}$ & $10 \mathrm{~min}$ \\
\hline Denaturation & $95^{\circ} \mathrm{C}$ & $45 \mathrm{~s}$ & $95^{\circ} \mathrm{C}$ & $45 \mathrm{~s}$ \\
\hline Annealing & $50^{\circ} \mathrm{C}$ & $45 \mathrm{~s}$ & $60^{\circ} \mathrm{C}$ & $45 \mathrm{~s}$ \\
\hline Elongation & $72^{\circ} \mathrm{C}$ & $45 \mathrm{~s}$ & $72^{\circ} \mathrm{C}$ & $2.5 \mathrm{~min}$ \\
\hline Final Elongation & $72^{\circ} \mathrm{C}$ & $10 \mathrm{~min}$ & $72^{\circ} \mathrm{C}$ & $10 \mathrm{~min}$ \\
\hline
\end{tabular}

\section{Preliminary evaluation of CPV-2 variation by RAPD}

RAPD method was used for the initial determination of variation in samples successfully isolated from cell cultures $(\mathrm{n}=50)$ and to select samples for sequencing. All DNA samples isolated from the blood were directly sequenced, without preliminary selection. RAPD reaction was carried out in a total volume of $25 \mu \mathrm{l}$ using the following temperature-time profile: initial denaturation at $94^{\circ} \mathrm{C}-2 \mathrm{~min}, 45$ cycles - denaturation $\left(94^{\circ} \mathrm{C}-60 \mathrm{~s}\right)$, primer annealing $\left(36^{\circ} \mathrm{C}-60 \mathrm{~s}\right)$, thread elongation $\left(72^{\circ} \mathrm{C}-60 \mathrm{~s}\right)$, final elongation- $10 \mathrm{~min}$. The PCR reaction was carried out using the Taq PCR Core Kit (Qiagen). Three primers were used: OPA 7 - 5'GAAACGGGTG 3', OPA 13 - 5' CAGCACCCAC 3' and OPH 12 - 5' ACGCGCATGT 3'. The reaction was carried out in a Sensoquest thermocycler. The reaction products were separated by electrophoresis in a $2.5 \%$ agarose gel with ethidium bromide in $1 \mathrm{xTBE}$ buffer, at a constant voltage of $70 \mathrm{~V}$ for 210 minutes. The lengths of the bands were determined by comparison to size markers. 


\section{Sequencing}

A representative of each of the variants obtained during RAPD amplification $(n=16)$ was sequenced and all isolates from the blood of animals with infection confirmed by PCR ( $n=10)$ were sequenced (in total 26 samples were sequenced). Products for the V2 primers were purified using the ExoSAP-IT kit (Affymetrix). Sequencing PCR was performed with the same primers as for the original amplification, using a BigDye ${ }^{\circledR}$ Terminator 3.1 CycleSequencing Kit (Applied Biosystems) as recommended by the manufacturer. Sequencing PCR products were purified with a DyeEx Spin Kit (Qiagen) on a QIAcube BioRobot (Qiagen). Samples were subjected to thermal denaturation in formamide. The sequencing reaction was carried out in a 3100 Avant Genetic Analyser (Applied Biosystems).

\section{Bioinformatic analysis}

Sequencing results were analyzed using DNA Baser software. The sequences used in the alignment were taken from the NCBI bioinformatic database. Editing and alignment of sequences were performed in MEGA6 software. The similarity between isolates was assessed in Bioedit software. Phylogenetic analysis was performed for the amino acid sequence obtained after translation of the nucleotides encoding the VP2 protein fragment in MEGA6 software. Maximum likelihood estimation at 1,000 bootstrap replications was used to construct a tree. Visualization of the tree was prepared in Figtree software.

\section{RESULTS}

A group of 116 dogs was tested with Speed Parvo test, and infection was confirmed in the case of 60 individuals. Feces from 50 of them were used for cell culture and virus isolation. The typical parvovirus associated cytopathic effects appeared in the cell cultures inoculated with the isolated virus. The specificity of the isolated virus was also confirmed by the hemagglutination test. The ability to agglutinate pig erythrocytes was confirmed in the case of each sample. Presence of viral DNA in the blood and cell cultures was confirmed with PCR with primers VP1 and VP2.

Optimization of PCR was aimed at the determination of the optimum annealing temperature and concentration of the reaction mixture components for both sets of primers. In the case of the VP1 primers, the greatest reaction efficiency was achieved at $50^{\circ} \mathrm{C}$ (Figure 1), which was confirmed by the presence of a bright band of $374 \mathrm{bp}$. A clear PCR product was obtained for each isolate from the blood, as well as from the cell cultures. The reaction protocol can be used to diagnose CPV-2 infections.

The optimum annealing temperature for the VP2 primer pair was $60^{\circ} \mathrm{C}$. Due to the longer product length, the elongation time had to be extended to 2.5 minutes. For the optimized protocol, a single specific product of approximately 2,487 bp (Figure 2) was obtained for each isolate and was the template in the sequencing reaction. 


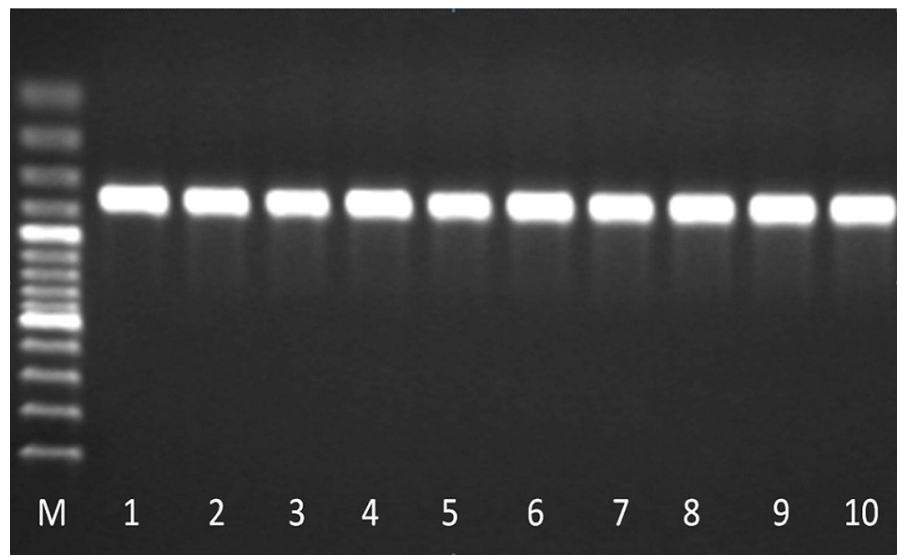

Figure 1. Electrophoretic separation of PCR products with VP1 primers in 1\% agarose gel. A distinct band of about 380 bp was obtained. $\mathrm{M}$ - size marker 100bp (with brighter bands 500 bp and 1000bp), 1-10 - test samples

RAPD analysis was prepared for the samples that were successfully isolated from the cell cultures $(\mathrm{n}=50)$. Results indicated that all isolates were grouped into 16 RAPD variants (Figure 3).

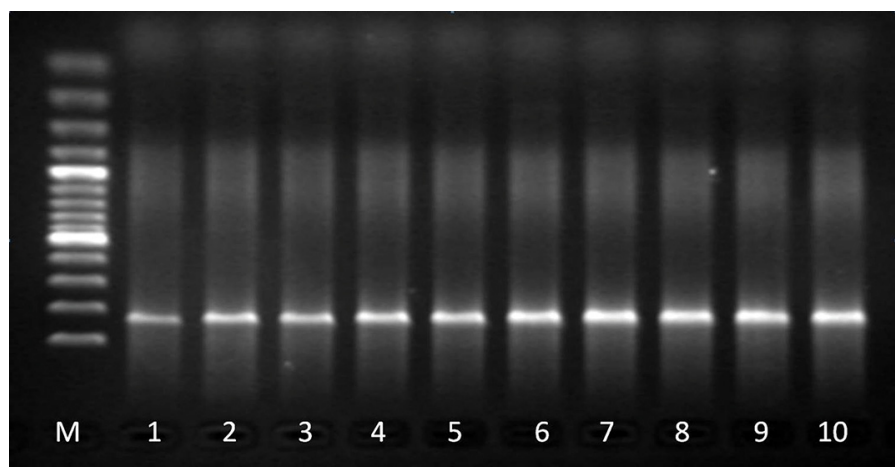

Figure 2. Electrophoretic separation of PCR products with VP2 primers in 1\% agarose gel. A distinct band of about 2,487 bp was obtained. $\mathrm{M}$ - size marker 100bp (with brighter bands 500bp and 1000bp), 1-10 - test samples

We sequenced 16 samples (representatives of each variant obtained from RAPD analysis) from cell cultures, and 10 from blood (26 samples in total). Based on the polymorphism in the nucleotide sequence, seven genetic variants were identified, with a similarity of over $99 \%$. The most common were variants IV $(n=9)$ and V $(n=5)$, remaining variants were detected with less frequency $(I-n=3, I I-n=2, I I I-$ $\mathrm{n}=3$, VI $-\mathrm{n}=2$ and VII $-\mathrm{n}=2$ ). The sequencing results were used to determine the similarity between the obtained variants. Based on polymorphism in the nucleotide sequence, seven genetic variants were identified, with similarity of over $99 \%$. Analysis of polymorphisms in the amino acid sequence indicated $100 \%$ similarity between variants I, IV, V and VI, in which the differences in the nucleotide sequence were 


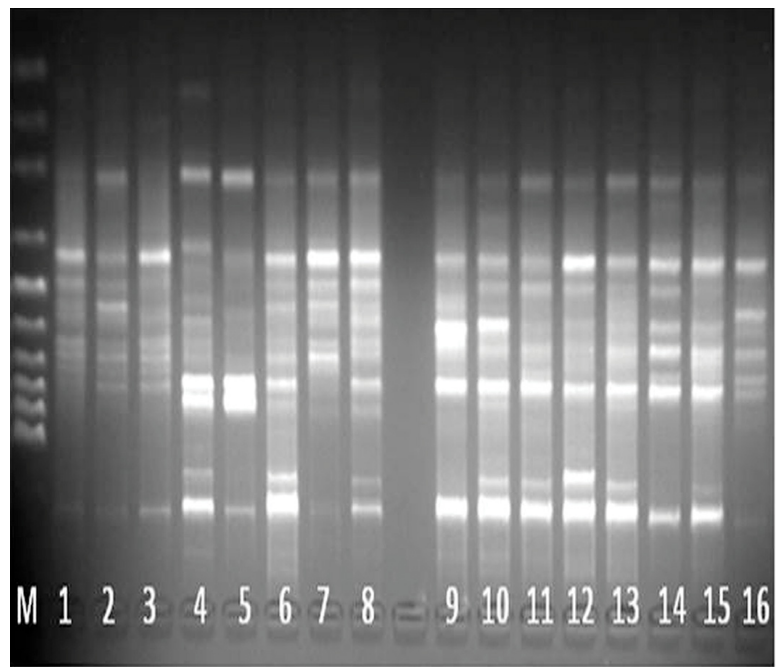

Figure 3. Electrophoretic separation of RAPD products with primers OPA 13 in 2,5\% agarose gel. $\mathrm{M}$ - size marker, 1-16 - test samples

synonymous. The variant that differed most from the remaining isolates was variant III; the difference was particularly pronounced in comparison to variants II and VII (the differences in the amino acid sequence exceeded 1\%) (Table 3).

Table 3. The similarity of nucleotide and protein sequences between obtained isolates (\%)

\begin{tabular}{cccccccc}
\hline \multirow{2}{*}{ Polish variants } & \multicolumn{7}{c}{ Nucleotide sequence } \\
\cline { 2 - 8 } & I & II & III & IV & V & VI & VII \\
\hline I & ID & 99.50 & 99.30 & 99.70 & 99.70 & 99.50 & 99.50 \\
II & 99.50 & ID & 99.30 & 99.30 & 99.70 & 99.50 & 99.50 \\
III & 99.30 & 99.30 & ID & 99.10 & 99.50 & 99.30 & 99.30 \\
IV & 99.70 & 99.30 & 99.10 & ID & 99.50 & 99.30 & 99.30 \\
V & 99.70 & 99.70 & 99.50 & 99.50 & ID & 99.70 & 99.70 \\
VI & 99.50 & 99.50 & 99.30 & 99.30 & 99.70 & ID & 99.50 \\
VII & 99.50 & 99.50 & 99.30 & 99.30 & 99.70 & 99.50 & ID \\
\hline \multirow{2}{*}{ Polish variants } & \multicolumn{7}{c}{ Protein sequence } \\
\hline I & ID & 99.30 & 99.30 & 100.00 & 100.00 & 100.00 & 99.30 \\
II & 99.30 & ID & 98.70 & 99.30 & 99.30 & 99.30 & 98.70 \\
III & 99.30 & 98.70 & ID & 99.30 & 99.30 & 99.30 & 98.70 \\
\hline IV & 100.00 & 99.30 & 99.30 & ID & 100.00 & 100.00 & 99.30 \\
V & 100.00 & 99.30 & 99.30 & 100.00 & ID & 100.00 & 99.30 \\
\hline VI & 100.00 & 99.30 & 99.30 & 100.00 & 100.00 & ID & 99.30 \\
VII & 99.30 & 98.70 & 98.70 & 99.30 & 99.30 & 99.30 & ID \\
\hline
\end{tabular}


In the polymorphism analysis, a particular focus was placed on the sequence encoding the main antigenic region in the capsid protein. Most of the tested isolates had asparagine at amino acid position 426 (Table 4), which is a crucial position for division into strains, indicating that they belonged to the CPV-2a strain, whereas the N426D substitution, common for CPV-2b was detected only in the case of variant number III. Substitution N426E, specific for CPV-2c, was not detected in any of the tested samples.

The presence of valine at position 555 made it possible to distinguish the new CPV-2a variants from the original type CPV-2a, which has isoleucine at this position.

The antigenic variant of each of the isolates was determined by comparing the sequences obtained with sequences from the NCBI database. The isolates represented by variants I, II, IV, V, VI and VII belonged to type CPV-2a, while variant III had theN426D substitution characteristic of type CPV-2b. In addition, in the case of variants II and VII, polymorphisms were noted that had not previously been observed - H543P (variant II) and N554D (variant VII). Analysis of polymorphisms in the amino acid sequence indicates the presence of four major groups in the parvovirus population. The first group consists of variants I, IV, V and VI, which are identical in terms of amino acid sequence and highly similar in nucleotide sequence (differences amounting to $0.3 \%-0.5 \%)$; the second group consists of variant II (H543P); the third group is represented by variant VII (N554D); and the fourth group by variant III, belonging to type CPV-2b.

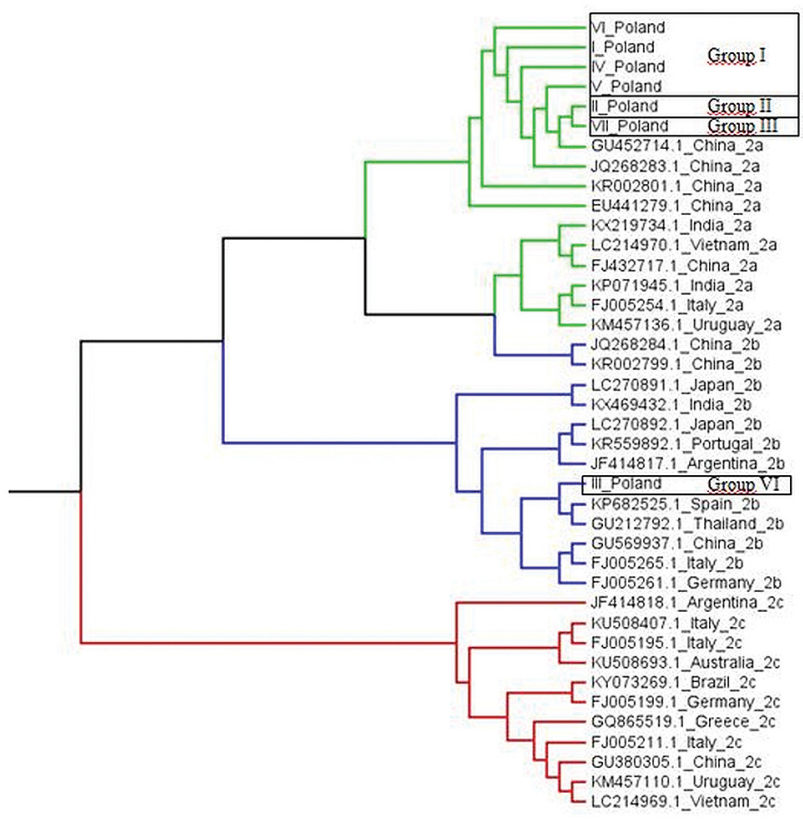

Figure 4. Phylogenetic analysis of strains available in the database and the Polish variants. Maximum likelihood estimation at 1,000 bootstrap replications was used to construct a tree (green - clad containing CPV-2a, blue - CPV-2b, red - CPV-2c) 
Table 4. Alignment of the Polish variants of CPV-2 with variants from the database. with underscored amino acid 426 enabling differentiation of CPV-2a, CPV-2b and CPV-2c (Polish variants - bolded. New amino acid substitution - italic)

\begin{tabular}{|c|c|c|c|c|c|c|c|c|c|c|c|c|c|c|}
\hline Variant & 426 & 434 & 439 & 440 & 543 & 554 & 555 & 560 & 562 & 564 & 568 & 573 & 579 & 580 \\
\hline I & $\mathbf{N}$ & D & $\mathbf{K}$ & $\mathbf{T}$ & $\mathbf{H}$ & $\mathbf{N}$ & V & $\mathbf{N}$ & V & S & G & $\mathbf{Y}$ & A & $\mathbf{P}$ \\
\hline II & . & . & . & . & $\boldsymbol{P}$ & . & . & . & . & . & . & . & . & . \\
\hline III & D & . & . & . & . & . & . & . & . & . & . & . & . & . \\
\hline IV & . & . & . & . & . & . & . & . & . & . & . & . & . & . \\
\hline V & . & . & . & . & . & . & . & . & . & . & . & . & . & . \\
\hline VI & . & . & . & . & . & . & . & . & . & . & . & . & . & . \\
\hline VII & . & . & . & . & . & $D$ & . & . & . & . & . & . & . & . \\
\hline KM457102.1_Uruguay_2a & . & . & . & A & . & . & . & . & . & . & . & . & . & . \\
\hline KR002800.1_China_2a & . & . & . & A & . & . & . & . & . & . & . & . & . & . \\
\hline KR002801.1_China_2a & . & . & . & . & . & . & . & . & . & . & . & . & . & . \\
\hline LC214970.1_Vietnam_2a & . & . & . & A & . & . & . & . & . & . & . & . & . & . \\
\hline KP071945.1_India_2a & . & . & . & A & . & . & . & . & . & . & . & . & . & . \\
\hline FJ432716.1_China_2a & . & . & . & . & . & . & . & . & . & . & . & . & . & . \\
\hline FJ432717.1_China_2a & . & . & . & A & . & . & . & . & . & . & . & . & . & . \\
\hline FJ005254.1_Italy_2a & . & . & . & A & . & . & . & . & . & . & . & . & . & . \\
\hline FJ005257.1_Italy_2a & . & . & . & . & . & . & . & . & . & . & . & . & . & . \\
\hline GU362932.1_Italy_2a & . & . & . & . & . & . & . & . & . & $\mathrm{N}$ & A & . & . & . \\
\hline KX219734.1_India_2a & . & . & . & A & . & . & . & . & . & . & . & . & . & . \\
\hline JQ268284.1_China_2b & $\mathrm{D}$ & . & . & A & . & . & . & . & . & . & . & . & . & . \\
\hline LC270892.1_Japan_2b & $\mathrm{D}$ & . & . & . & . & . & . & . & $\mathrm{L}$ & . & . & . & . & . \\
\hline FJ005261.1_Germany_2b & $\mathrm{D}$ & . & . & . & . & . & . & . & . & . & . & . & . & . \\
\hline FJ005262.1_Italy_2b & $\mathrm{D}$ & $\mathrm{V}$ & $\mathrm{N}$ & . & . & . & . & . & . & . & . & . & . & S \\
\hline FJ005263.1_Italy_2b & $\mathrm{D}$ & . & . & . & . & . & . & . & . & . & . & . & . & . \\
\hline GU212792.1_Thailand_2b & $\mathrm{D}$ & . & . & . & . & . & . & . & . & . & . & $\mathrm{F}$ & . & . \\
\hline GU569937.1_China_2b & $\mathrm{D}$ & . & . & . & . & . & . & . & . & . & . & . & . & . \\
\hline JF414817.1_Argentina_2b & $\mathrm{D}$ & . & . & . & . & . & . & . & . & . & . & . & . & . \\
\hline KR559895.1_Portugal_2b & $\mathrm{D}$ & . & . & . & . & . & . & . & . & . & . & . & . & . \\
\hline KX469432.1_India_2b & $\mathrm{D}$ & . & . & . & . & . & . & . & . & . & . & . & . & . \\
\hline KP682525.1_Spain_2b & $\mathrm{D}$ & . & . & . & . & . & . & . & . & . & . & . & . & . \\
\hline KY073269.1_Brazil_2c & $\mathrm{E}$ & . & . & . & . & . & . & . & . & . & . & . & . & . \\
\hline KU508407.1_Italy_2c & $\mathrm{E}$ & . & . & . & . & . & . & . & . & . & . & . & . & . \\
\hline KM457110.1_Uruguay_2c & $\mathrm{E}$ & . & . & . & . & . & . & . & . & . & . & . & $\mathrm{V}$ & . \\
\hline KU508691.1_Australia_2c & $\mathrm{E}$ & . & . & . & . & . & . & . & . & . & . & . & . & . \\
\hline LC214969.1_Vietnam_2c & $\mathrm{E}$ & . & . & . & . & . & . & . & . & . & . & . & . & . \\
\hline FJ005195.1_Italy_2c & $\mathrm{E}$ & . & . & . & . & . & . & K & . & . & . & . & . & . \\
\hline FJ005196.1_Germany_2c & $\mathrm{E}$ & . & . & . & . & . & . & . & . & . & . & . & . & . \\
\hline GQ865518.1_Greece_2c & $\mathrm{E}$ & . & . & . & . & . & . & . & . & . & . & . & . & . \\
\hline GU380303.1_China_2c & $\mathrm{E}$ & . & . & . & . & . & . & . & . & . & . & . & . & . \\
\hline JF414818.1_Argentina_2c & $\mathrm{E}$ & . & . & . & . & . & . & . & . & . & . & . & . & . \\
\hline
\end{tabular}

The phylogenetic analysis indicates that the isolates from groups I-III belong to type CPV-2a, together with the variants recorded in China (Figure 4). A separate branch in the same clade is occupied by isolates from Italy, India and Vietnam. The Polish CPV$2 \mathrm{a}$ variants constitute a monophyletic group within an antigenic type. A representative 
of the third group clearly belongs to type CPV-2b, together with isolates from Italy, Spain and Germany. None of the variants obtained was matched to type CPV-2c.

\section{DISCUSSION}

The molecular epidemiology of CPV-2 in Poland is still poorly understood, and research in this area has previously been undertaken only by Mizak and Rzeżutko [15] and by Majer-Dziedzic et al. [16]. The authors performed a molecular characterization of CPV-2 variants circulating in Poland, contributing to the global map of CPV-2 epidemiology [17-23]. The usefulness of the PCR method and its modifications in the diagnosis of parvoviral diseases has been confirmed by numerous researchers [2426]. The technique has enabled the detection of viral material from both blood and cell cultures. The V1 primers may be particularly important in routine diagnosis of parvovirus infection in dogs; the short amplification product allows for analysis of highly degraded samples, which is particularly important when DNA is to be isolated from difficult biological material, including feces or rectal swabs in the case of CPV-2.

RAPD method may be used for the initial selection of samples to further analysis. Some variants obtained after RAPD analysis, showed identical nucleotide sequences coding the VP2 protein. This fact may be caused by the variation in the parts of genomes which were not amplified during PCR analysis. RAPD method generates more variants than PCR as the technique targets the whole genome. Therefore, RAPD may be especially useful for the initial selection of samples to NGS analysis.

The V2 primers flanking the entire VP2 protein can be used for genotyping and phylogenetic analyses of CPV-2. Bioinformatic analysis confirmed the high variability at the nucleotide level, and seven variants were distinguished. The synonymous nature of polymorphisms in the nucleotide sequence was the basis for including variants I, IV, V, VI in one group. Isolates included in groups II and III differed in single substitutions in the amino acid sequence and belonged to type $2 \mathrm{a}$ (which in previous studies was considered the main antigenic variant in Poland in the 1980s [16, 27]) and $2 \mathrm{~b}$ respectively.

The CPV-2 virus exhibits high variability, which entails changes in its pathogenicity and antigenic structure. The high adaptability of the pathogen is evidenced by the fact that by the late 1980s the parent variant had been completely supplanted by the new CPV-2a and CPV-2b variants $[3,28]$, which differed in a single amino acid change in the VP2 protein sequence. At the start of the 21 st century, the occurrence of another variant was confirmed in Italy and was designated CPV-2c [17]. It differed from the previous $2 \mathrm{~b}$ strain in a single amino acid change in the main epitope region. In Italy and Argentina the CPV-2c strain is becoming the dominant variant, supplanting the $2 \mathrm{a}$ and $2 \mathrm{~b}$ isolates previously circulating in the environment [21]. Zhao et al. point out the importance of amino acid position 440 [5], which is part of the major antigenic region [29]. Nearly $80 \%$ of isolates obtained by researchers have alanine in this position. 
This mutation was not noted in Polish isolates, as each of the variants obtained had threonine in position 440. Xu et al. believe that the T440A mutation may play a role in the process of local adaptation, making it easier for the pathogen to remain in the population [2]. Position 555 also plays an important role, with isoleucine present in the case of the old CPV-2a, while the I555V substitution appears in the new type.

For Poland, there are few data available on the molecular epidemiology of CPV-2. The analyses of the amino acid sequence and phylogenetic relationships are partially confirmed by results obtained by Majer-Dziedzic et al. [16] and by Mizak and Plucienniczak [30], who assigned Polish variants to the CPV-2a strain. In contrast to the results obtained by Majer-Dziedzic et al. [16], the present study did not reveal the presence of type CPV-2c, and type CPV-2a was clearly dominant.

An increasing number of studies confirm the emergence of new variants belonging to types CPV-2a and CPV-2b [31, 32], which exhibit changes in the amino acid sequence in relation to the original types. Polish isolates, containing H543P and N554D substitutions seem to support this hypothesis. Poland is not the only country with recurrence of CPV-2a infection. A return of the CPV-2a variant has also been noted in Argentina, where although CPV-2c is still the dominant type, the presence of type $2 \mathrm{a}$ has been confirmed for the first time since 2008 [33]. Filipov et al. [34], in a study on the epidemiology of canine parvovirus infection in Bulgaria, confirmed the dominance of CPV-2a, and the same antigenic type was detected in isolates from Hungary [35]. A similar trend was observed in Turkey by Timurkan and Oguzoglu [36], who noted variant $2 \mathrm{a}$ in almost $70 \%$ of infected animals, while CPV-2c was not detected. However, in the studies of Purpari et al. [37] conducted in Italy, the CPV-2c type was dominant (almost 80\%). Dominance of CPV-2a and CPV-2b is also noted in Asian countries such as China [38] or India [7], as well as in Australia [39].

The Polish isolates, despite 99\% nucleotide similarity, display differences in the VP2 protein sequence which may affect its antigenicity. The fact that four groups were distinguished, including one belonging to CPV-2b, indicates that the pathogen is continually adapting to local conditions and evolving in different directions. The dominant group I, consisting of four variants differing in synonymous substitutions, may be the original starting pool that forms the basis for new genetic variants of CPV2 in Poland. In view of the high evolutionary dynamics of CPV-2, continual research on the molecular epidemiology of the canine parvovirus is essential to obtain the most accurate possible understanding of the molecular structure of CPV isolates occurring in Poland.

\section{Acknowledgements}

Sequences obtained during this study are available in GenBank with the accession numbers: MK433549-MK433555. 


\section{Authors' contributions:}

KM-PCR optimization, amplification and electrophoresis of obtained fragments, bioinformatic processing obtained results, preparing and formatting the manuscript to publication. MDB-samples collection, cell culture preparation. KK-Co-author of research hypothesis, preparing and formatting the manuscript to publication. SAAmplification and electrophoresis of obtained fragments. ZJ -Samples collection. GM-Preparation of the manuscript for publication. JA-Authorship of the research hypothesis (the idea of the experiment), a lead role in planning the experiment, PCR optimization, sequencing alanalysis of obtained fragments, bioinformatic processing obtained results, preparing and formatting the manuscript to publication. All authors have approved the final version of the manuscript.

\section{Declaration of conflicting interests:}

The author(s) declared no potential conflicts of interest with respect to the research, authorship, and/or publication of this article.

\section{REFERENCES}

1. Patial S, Chaturvedi VK, Rai A, Saini M, Chandra R, Saini Y, Gupta PK:. Virus neutralizing antibody response in mice and dogs with a bicistronic DNA vaccine encoding rabies virus glycoprotein and canine parvovirus VP2. Vaccine 2007, 25:4020-4028.

2. Xu J, Guo HC, Wei YQ, Shu L, Wang J, Li JS, Cao SZ, Sun SQ: Phylogenetic analysis of canine parvovirus isolates from Sichuan and Gansu provinces of China in 2011. Transbound Emerg Dis 2015, 62:91-95.

3. Decaro N, Buonavoglia C: Canine parvovirus-A review of epidemiological and diagnostic aspects, with emphasis on type 2c. Vet Microbiol 2012,155:1-12.

4. Perez R, Bianchi P, Calleros L, Francia L, Hernandez M, Maya L, Panzera Y, Sosa K, Zoller $\mathrm{S}$ : Recent spreading of a divergent canine parvovirus type $2 \mathrm{a}(\mathrm{CPV}-2 \mathrm{a})$ strain in a CPV-2c homogenous population. Vet Microbiol 2012, 155:214-219.

5. Zhao H, Wang J, Jiang Y, Cheng Y, Lin P, Zhu H, Han G, Yi L, Zhang S, Guo L, Cheng S: Typing of Canine Parvovirus Strains Circulating in North-East China. Transbound Emerg Dis 2017, 64:495-503.

6. Shackelton LA, Parrish CR, Truyen U, Holmes EC: High rate of viral evolution associated with the emergence of carnivore parvovirus. Proc Natl Acad Sci USA 2005, 102:379-384.

7. Nandi S, Kumar M: Canine parvovirus: current perspective. Indian J Virol 2010, 21(1): 31-44

8. Desario C, Decaro N, Campolo M, Cavalli A, Cirone F, Elia G, Martella V, Lorusso E, Camero M, Buonavoglia C: Canine parvovirus infection: Which diagnostic test for virus? J Virol Methods 2005, 126:179-185.

9. Kowalczyk M, Jakubczak A: Prospects for the use of molecular methods in the diagnosis of parvovirus type 2 (CPV-2) in representatives of the Canidae family. Med Weter 2016, 72(1):7-11. 
10. Decaro N, Elia G, Desario C, Roperto S, Martella V, Campolo M, Lorusso A, Cavalli A, Buonavoglia C: A minor groove binder probe real-time PCR assay for discrimination between type 2-based vaccines and field strains of canine parvovirus. J Virol Methods 2006, 136:65-70.

11. Streck AF, Ruster D, Truyen U, Homeier T: An updated TaqMan real-time PCR for canine and feline parvoviruses. J Virol Methods 2013, 193:6-8.

12. Eibach D, Krumkamp R, Hahn A, Sarpong N, Adu-Sarkodie Y, Leva A, Kasmaier J, Panning M, May J, Tannich E: Application of a multiplex PCR assay for the detection of gastrointestinal pathogens in a rural African setting. BMC Infect Dis2016, 16(1).

13. Kumar M, Chidri S, Nandi S: A sensitive method to detect canine parvoviral DNA in faecal samples by nested polymerase chain reaction. Indian J Biotechnol 2011, 10:183-187

14. Amrani N, Desario C, Kadiri A, Cavalli A, Berrada J, Zro K, Sebbar G, Colaianni ML, Parisi A, Elia G, Buonavoglia C, Malik J, Decaro N: Molecular epidemiology of canine parvovirus in Morocco. Infect Genet Evol 2016, 41:201-206.

15. Mizak B, Plucienniczak A: Antigenic typing Polish isolates of canine parvovirus. Bull Vet Inst Pulawy1995, 39:71-76

16. Majer-Dziedzic B, Jakubczak A, Zietek J: Phylogenetic analysis of canine parvovirus CPV-2 strains and its variants isolated in Poland. Pol J Vet Sci2011, 14(3):379-384

17. Buonavoglia C, Martella V, Pratelli A, Tempesta M, Cavalli A, Buonavoglia D, Bozzo G, Elia G, Decaro N, Carmichael L: Evidence for evolution of canine parvovirus type 2 in Italy. J Gen Virol 2001, 82:3021-3025.

18. Hong C, Decaro N, Desario C, Tanner P, Pardo MC, Sanchez S, Buonavoglia C, Saliki JT: Occurrence of canine parvovirus type 2c in the United States. J Vet Diagn Invest 2007, 19:535-539.

19. Calderon MG, Mattion N, Bucafusco D, Fogel F, Remorini P, Torre J: Molecular characterization of canine parvovirus strains in Argentina: Detection of the pathogenic variant CPV2c in vaccinated dogs. J Virol Methods2009, 159:141-145.

20. Ohshima T, Hisaka M, Kawakami K, Kishi M, Tohya Y, Mochizuki M: Chronological analysis of canine parvovirus type 2 isolates in Japan. J Vet Med Sci 2008, 70:769-775.

21. Vieira MJ, Silva E, Oliveira J, Vieira AL, Decaro N, Desario C, Muller A, Carvalheira J, Buonavoglia C, Thompson G: Canine parvovirus 2c infection in central Portugal. J Vet Diagn Invest 2008, 20:488-491.

22. Nandi S, Chidri S, Kumar M, Chauhan RS: Occurrence of canine parvovirus type $2 \mathrm{c}$ in the dogs with haemorrhagic enteritis in India. Res Vet Sci 2010, 88:169-171

23. Yang D-K, Byun J-I, Song J-Y, Yoon S-S, Lee K-W, Oh Y-I: Serological Survey for Canine Parvovirus Type 2a (CPV-2a) in the Stray Dogs in South Korea. J BacteriolVirol2010, 40:77-81.

24. Uwatoko K, Sunairi M, Nakajima M, Yamaura K: Rapid method utilizing the polymerase chain reaction for detection of canine parvovirus in feces of diarrheic dogs. Vet Microbiol 1995, 43:315-323

25. Decaro N, Elia G, Martella V, Desario C, Campolo M, Di Trani L, Tarsitano E, Tempesta M, Buonavoglia C: A real-time PCR assay for rapid detection and quantitation of canine parvovirus type 2 in the feces of dogs. Vet Microbiol 2005, 105:19-28.

26. Sun Y-L, Yen C-H \& Tu C-F: Visual Detection of Canine Parvovirus Based on LoopMediated Isothermal Amplification Combined with Enzyme-Linked Immunosorbent Assay and with Lateral Flow Dipstick. J Vet Med Sci 2014, 76:509-516. 
27. Rypula K, ChmielewskiR,Smielewska-Łos E,Klimentowski S: Phylogenic similarity of the canine parvovirus wild-type isolates on thebasis of VP1/VP2gene fragment sequence analysis. J Vet Med B 2002, 49:142-145

28. Organtini LJ, Allison AB, Lukk T, Parrish CR, Hafenstein S. Global Displacement of Canine Parvovirus by a Host-Adapted Variant: Structural Comparison between Pandemic Viruses with Distinct Host Ranges. J Virol 2015, 89:1909-1912.

29. Battilani M, Ciulli S, Tisato E, Prosperi S: Genetic analysis of canine parvovirus isolates (CPV-2) from dogs in Italy. Virus Res 2002, 83:149-157

30. Mizak B, Plucienniczak A: Antigenic typing Polish isolates of canine parvovirus. Bull Vet Inst Pulawy 1995, 39:71-76

31. Decaro N, Desario C, Campolo M, Elia G, Martella V, Ricci D, Lorusso E, Buonavoglia C: Clinical and virological findings in pups naturally infected by canine parvovirus type 2 Glu426 mutant. J Vet Diagn Invest 2005, 17:133-138.

32. Duque-Garcia Y, Echeverri-Zuluaga M, Trejos-Suarez J, Ruiz-Saenz J: Prevalence and molecular epidemiology of Canine parvovirus 2 in diarrheic dogs in Colombia, South America: A possible new CPV-2a is emerging? Vet Microbiol 2017, 201:56-61.

33. Gallo Calderon M, Romanutti C, Wilda M, D’Antuono A, Keller L, Giacomodonato MN, Mattion N, La Torre J: Resurgence of canine parvovirus 2a strain in the domestic dog population from Argentina. J Virol Methods 2015, 222:145-149

34. Filipov C, Desario C, Patouchas O, Eftimov P, Gruichev G, Manov V, Filipov G, Buonavoglia C, Decaro N: A Ten-Year Molecular Survey on Parvoviruses Infecting Carnivores in Bulgaria. Transbound Emerg Dis 2016, 63:460-464

35. Csagola A, Varga S, Lorincz M., Tuboly T: Analysis of the full-length VP2 protein of canine parvoviruses circulating in Hungary. Arch Virol 2014, 159:2441-2444.

36. Timurkan MO, Oguzoglu TC: Molecular characterization of canine parvovirus (CPV) infection in dogs in Turkey. Vet Ital 2015, 51:39-44

37. Purpari G, Mira F, Di Bella S, Di Pietro S, Giudice E, Guercio A: Investigation on canine parvovirus circulation in dogs from sicily (Italy) by biomolecular assai. Acta Vet-Beograd 2018, 68: 80-94

38. Zhong ZJ, Liang LQ, Zhao J., Xu XY, Cao XF, Liu XH, Zhou ZY, Ren ZH, Shen LH, Geng Y, Gu XB, Peng GN: First Isolation of New Canine Parvovirus 2a from Tibetan Mastiff and Global Analysis of the Full-Length VP2 Gene of Canine Parvoviruses 2 in China. Int J MolSci2014, 15:12166-12187.

39. Meers J, Kyaw-Tanner M, Bensiw Z, Zwijnenbergh R: Genetic analysis of canine parvovirus from dogs in Australia. Aust Vet J 2007, 85:392-396. 


\title{
DIJAGNOSTIKA I GENOTIPIZIRANJE PARVOVIRUSA PASA TIP-2 (CPV-2) KOD OBOLELIH PASA U JUGOISTOČNIM REGIONIMA POLJSKE
}

\author{
KOWALCZYK Marek, MAJER-DZIEDZIC Barbara, KOSTRO Krzysztof, \\ SZABELAK Aleksandra, ZIĘTEK Jerzy, GRYZINSKA Magdalena, \\ JAKUBCZAK Andrzej
}

Parvovirus pasa tip-2 je jedan od najčešćih uzročnika uginuća štenadi. Uprkos postojanju preventivne vakcinacije, oboljene nastavlja da se dijagnostikuje. Cilj studije je bio da se obavi molekularna karakterizacija CPV-2 izolata iz slučajeva obolele štenadi u jugoistočnim regionima Poljske. Genetski materijal CPV-2 je izolovan iz krvi $(n=10)$ i fecesa $(n=50)$ zaraženih pasa. Prisustvo CPV-2 je dokazano amplifikacijom sekvenci virusa koje kodiraju VP1 i VP2 proteine. Proizvodi PCR reakcije sa prajmerima za amlifikaciju VP2 virusnog proteina su sekvencionisani i upotrebljeni u cilju genotipiziranja. Bioinformatička analiza sekvencionisanih PCR produkata je obavljena sa ciljem da se ustanovi filogenetska povezanost sa varijantama virusa koje se nalaze u dostupnim bazama podataka. $\mathrm{Na}$ osnovu analiza polimorfizima u nukleotidnim sekvencama, pronađeno je sedam nukleotidnih varijanti koje su svrstane u četiri aminokiselinske grupe. Predstavnici tri grupe su sadržavali asparagin na aminokiselinskoj poziciji 426 VP2 proteina, što je karakteristika CPV-2a. Varijanta iz četvrte grupe je spadala u tip CPV-2b. U Poljskoj, dominantno se nalazi CPV-2a tip virusa. Visok nivo polimorfizma ovog virusa se manifestuje ne samo u odnosu na veći broj varijanti u okviru tipa već i prisustvom predstavnika CPV-2b. Neophodno je da se obave dalja molekularno epizootiološka istraživanja CPV-2, a radi dobijanja optimalnih rezultata i efekata preventivnih mera parvovirusne infekcije pasa. 